\title{
A Research into the Reform of College English Teaching Based on Cultivating "Critical Thinking Skills"
}

\author{
Qinning Wu \\ Nanchang Institute of Science \& Technology, Nanchang 330108, China
}

\begin{abstract}
The teaching reform is being carried out in colleges and universities all over the country. As a basic course, college English has also been reformed under the new situation. However, how to improve students' critical thinking skills has is still unsolved. This article intends to explore the necessity and method of cultivating students' critical thinking skills in college English teaching.

Keywords: Teaching Reform; College English; Critical Thinking Skills
\end{abstract}

\section{I.Introduction}

The development of critical thinking skills is one of the core goals of higher education in our country. In July 2010, the Ministry of Education issued the Outline of the National Medium- and Long-Term Education Reform and Development Plan (2010-2020), which clearly stated that the long-term development of education needs to "promote the comprehensive development of students and improve the social responsibility of serving the people, the courage to explore the spirit of innovation and ability to solve practical problem". It also advocates heuristic, exploratory, discussed, participatory teaching to help students learn the way of learning and create independent thinking, freedom to explore and innovative environment." Thus, the cultivation and development of students' critical thinking skills is not only an obligatory duty of educators, but also the national long-term development strategic task. However, for a long time, our students' abilities in the analysis, reasoning, evaluation, synthesis, discrimination and so on are not satisfactory. Huang Yuanshen (1998) pointed out that the lack of this ability can be described as "critical thinking absence." There are many 
reasons for the "critical thinking absence." The insufficient attention to the students' critical thinking skills is one of the reasons. In view of this, the author thinks that we should construct the mode of cultivating the critical thinking skills of college English teaching on the basis of critical thinking-oriented teaching method, and push the reform of college English teaching in depth in order to cultivate useful talents with excellent English skills and thinking ability. As a basic English course teacher, after more than three years of reform, the author believes that the process of teaching reform is like the formation of skills, which will experience the process of sprout $\rightarrow$ high-speed development period $\rightarrow$ recession $\rightarrow$ recovery period $\rightarrow$ high-speed development period.

Throughout the three years of teaching reform, we have made great innovations in curriculum design, teaching materials selection, training mode and so on. Nevertheless, the performance of cultivating students' ability of thinking is not very effective. But, as a qualified college students, having knowledge is not enough, what is more important is to have the ability to find, analyze and solve problems. Therefore, the cultivation and development of students' critical thinking skills has become the top priority for all universities of our country

In order to realize the cultivation and development of students' critical thinking skills in college English teaching, researchers should first understand the conception of the critical thinking skills and the present situation and so on. Then researchers discuss how teachers should do in college English class, combining with the teaching of thinking.

\section{Research Summary for "Critical Thinking Skills"}

Critical thinking is actually the unity of cognitive skills and affective disposition. Cognitive skills include three aspects, such as analysis, reasoning and evaluation. The affective dispositions include curiosity, openness, self-confidence, integrity and perseverance (Wen Qiufang 2009: 42). Critical thinking skills are constructive and innovative, which can make students explain the phenomenon from a broader perspective and make a multi-dimensional analysis judgment for studying object, propose more solutions to the problem. Critical thinking skill is to cultivate a person the way of learning with a critical thinking to look at the problem, rather than accept all knowledge sticking to the rules. And many students just lack this ability, but they simply attach importance to the memory of the word, sentence training and other skills training, the ability to speculate is very weak, which makes their language ability is difficult to progress.

2. Related Research Review At Home and Abroad

In the research field of critical thinking, Western countries have been at the forefront of various types of research results. Wen Qiufang et al. (2009) pointed out that in the past 20 years, Western countries have paid more and more attention to the research of students' thinking ability. Their research can be roughly divided into three categories: (1) the ability to define "critical thinking skills"; (2) the ability to build a speculative tool; (3) to explore the access and 
effectiveness of cultivating critical thinking on higher education. Li Liwen (2011) also reviewed the research on critical thinking both at home and abroad. She indicated that the influential theoretical frameworks include the mode of two-dimensional structure proposed by The Delphi Project (including cognitive elements and affective elements), the model of three-edge structure given by Lin Chongde (including the purpose of thinking, thinking process, thinking material, thinking self-monitoring, thinking quality, cognitive and non-cognitive factors in thinking), Wen Qiufang's level theoretical models (including the first level of meta-thinking ability and the second level of thinking ability). In the above-mentioned models, all attract many attentions because of its intuition and operability.

English is a subject has strong humanities, its teaching can not only stay in the listening, speaking, reading, writing, translation and other skills training, but guide students to think in the teaching process. At the same time, teachers should also strengthen the infiltration of humanistic knowledge and cultivate students' ability of speculation. Over the years, scholars are increasingly concerned about the theory and practical research on critical thinking skills of students and emerge a number of research results.

By summarizing the relevant literature, the author found that these studies have three main characteristics: (1)most of the related researches focus on English majors, and few of them focus on non-English majors' critical thinking skills; (2)empirical research that can be applied to practical classroom teaching is rare; (3)most of the researches only reveal "what is the problem", "how to solve the problem" is not studied deeply and operability of college English teaching is hard to find.

\section{III.Current Situation of Critical Thinking Skills in English Teaching}

College English teaching is an integral part of higher education in our country. But, in contrast to the present teaching situation of college English, we will find that the skills of listening, speaking, reading, writing and translation which are praised by the educators in previous years are still on the basis of "memorizing" and "understanding". Teaching content can be separated from the "language point" of "memorizing" and "understanding" is rare. And the highest expressions of critical thinking are the analysis, judgment and creation to an object, not just to master a certain skill. English is a humanities, English teaching should not be limited to the training of certain skills, but penetrate the critical thinking skills effectively in the teaching process and develop students divergent thinking and problem-solving skills.

All along, the college English teaching doesn't pay much attention to students' critical thinking skills. The main goal of the course is to develop the basic language skills of listening, speaking, reading, writing and translation. The course is centered on these skills, and the assessment method is mainly English level test. 
As a result, students often only pay attention to language skills, put their back into memorizing new words and practice sentences, etc., which neglect developing critical thinking. Thus, it is very hard to improve students' integrated language skills effectively. This shows that students' have no strong communicative competence and are not good at analyzing and thinking when communicating with others. Also, college students' comprehensive judgment and reasoning inductive ability is insufficient, language organization lacks coherence, logic and accuracy. For example, in the oral English activities such as the English salon, students' communications are limited in some simple conversations in daily life, who are difficult to conduct a discussion on a problem deeply and thoroughly.

\section{IV.New Mode for Cultivating "Critical Thinking Skills"}

So far, the teaching reform of college English has undergone several times, but there are still many problems. The core of the problem is that students are not interested in this course. Many students are utilitarian to pursue the purpose of finding a good job in the future by passing the CET examination. Therefore, they are quite passive in the learning process. By using the research results of Wen Qiufang(2009) and Liu Xiaomin (2013) for reference, the author thinks that the cultivation of critical thinking should be based on the following points:

In classroom teaching, teachers should cultivate students' ability to express their views, and evaluate students' performance promptly and accurately, so that students are willing to express their views, and then expand their thinking space. For example: when the author teaches the third unit "Food and Drink" in the textbook "Let's talk", the author divides students into groups, each one thinks out a most representative home cooking and translate it into English. Later on, students can find out other translations by searching online. Finally, they discuss in group that which one is better, and why? Students can consolidate the practical application of knowledge in the discussion; furthermore, classroom atmosphere is also very active. In this way, , it both improves the language skills of students and trains their thinking skills through the role of positive emotional factors.

At present, Most of English teaching is in the teaching and learning of "knowledge points", while the western developed countries rely on teaching content. Language is only a kind of medium and tools. Students acquire knowledge through language. Meanwhile, they usually improve the language skills and critical thinking skills through the subject knowledge learning. Our country's teaching practice intends to train students' ability to analyze, solve problems and think independently by combining the critical thinking skills and subject knowledge on the basis of content-oriented teaching method.

Autonomous learning is a very important way of learning, which can exercise the students' ability to act independently. Teachers can guide students to read a story, and rewrite the different end of the story in order to give full play of students' critical thinking skills. Therefore, teachers should mobilize the initiative of students as much as possible, and spare no efforts to combine the language 
ability and thinking ability of students' effectively. Furthermore, each student has different characteristics, teachers should be aware of the differences of students, students can not be regarded as the same, with the same method to teach all students.

Course evaluation in the course of teaching is particularly important, but also an important means of testing the quality of teaching. Evaluation methods should also has the purpose of improving students' critical thinking skills: 1) a variety of evaluation methods, such as group discussions, performances, presentations, rewriting and other creative forms; 2) the integration of speculative testing methods, the use of formative assessment mechanism; 3) clear the criteria for speculative proficiency.

\section{Conclusion}

In summary, the development of students' thinking skills is a long and arduous goal. teachers will combine critical thinking with teaching content, independent learning, evaluation methods, etc. and be imperceptible in the daily teaching infiltration to improve students' critical thinking skills gradually.

\section{Reference:}

[1] Golden, J.L., G. F. Berquist and W. E. Coleman. The Rhetoric of Western Thought $[\mathrm{M}] 7^{\text {th }}$ Edition. Dubuque: Kendall/Hunt Publishing Company, 2000:3

[2] Huang Yuanshen The Absence of Critical Thinking Skills [J]. Foreign Language and Foreign Language Teaching. 1998, (7): 1, 19.

[3] Liu Xiaomin Mode of Critical Thinking On the Construction of College English Teaching [J].

Foreign Language. 2013, (5)

[4] Littlewood W. Learner Autonomy: Definition, Issues and Problems [M]. Dublin: Authentic, 1991.

[5] Mohan B A. Language and Content [M]. Reading, MA: Addison Wesley, 1986.

[6] Stryker S \& Leaver B (eds.). Content-based Instruction in Foreign Language Education: Models and Methods [C]. Washington, D.C.: Georgetown University Press, 1997. 